\title{
Ocean climate and prey availability affect the trophic level and reproductive success of the marbled murrelet, an endangered seabird
}

\author{
Benjamin H. Becker ${ }^{1,2, *}$, M. Zachariah Peery ${ }^{1,3}$, Steven R. Beissinger ${ }^{1}$ \\ ${ }^{1}$ Division of Ecosystem Sciences, Department of Environmental Science, Policy and Management, 137 Mulford Hall No. 3114 , \\ University of California, Berkeley, California 94720-3114, USA \\ ${ }^{2}$ Present address: Pacific Coast Science and Learning Center, Point Reyes National Seashore, Point Reyes Station, \\ California 94956, USA \\ ${ }^{3}$ Present address: 7544 Sandholdt Road, Moss Landing Marine Laboratories, Moss Landing, California 95039, USA
}

\begin{abstract}
We investigated relationships between oceanographic processes, prey availability, diet and the reproductive success of the marbled murrelet Brachyramphus marmoratus (Alcidae), a federally threatened seabird. We predicted that cooler ocean conditions (which increase primary productivity in this eastern boundary upwelling system) should result in heightened prey availability and hence higher reproductive success for the murrelet. We also expected that murrelet diets should reflect those potential prey species that are most abundant during any given season or year. Oceanographic conditions were considered at 2 spatial scales: synoptic (Northern Oscillation Index, NOI; Pacific Decadal Oscillation Index, PDO; the North Pacific Index, NPI), and local (upwelling index, UI; sea surface temperature, $\mathrm{SST}_{i}$ strength of the spring turnover). To infer seasonal and annual variation in murrelet diets in central California, we used stable isotope analyses of $\delta^{15} \mathrm{~N}$ and $\delta^{13} \mathrm{C}$ in murrelet feathers and prey tissues during the pre- and postbreeding seasons of 1998 to 2002. Isotopic signatures of 10 species of potential prey clustered into 3 distinct groups (low, mid and high trophic level seabird prey). During 1999 to 2001, when more krill (low trophic level prey) were available, murrelet $\delta^{15} \mathrm{~N}$ and trophic level were lower prior to breeding than after breeding, whereas pre- and postbreeding diets were similar during 1998 and 2002 when fewer krill were available. $\delta^{13} \mathrm{C}$ was always lower in prebreeding than postbreeding diets, which tracked availability of ${ }^{13} \mathrm{C}$ enriched juvenile rockfish and market squid. Diet did not differ by sex for either isotope. Murrelet productivity (juvenile:adult ratios) was positively correlated with both rockfish and krill abundance. PDO, NOI, UI, spring turnover strength and NPI indices were unrelated to murrelet productivity and to prey abundances. Murrelet productivity was also positively related to the proportion of mid trophic level prey in postbreeding diets, and thus negatively related to the proportion of low and high trophic level prey consumed. Furthermore, productivity was markedly higher following the apparent 1998 to 1999 PDO regime shift to cooler conditions. These data suggest that cooler local temperatures support increased availability of krill and juvenile rockfish to murrelets, and that this improves murrelet reproductive success.
\end{abstract}

KEY WORDS: Stable isotope $\cdot$ Marbled murrelet $\cdot$ Seabird $\cdot$ Diet shift $\cdot$ Brachyramphus marmoratus Resale or republication not permitted without written consent of the publisher

\section{INTRODUCTION}

Reproductive success in birds is mediated by a variety of factors including food availability, predation, competition, nest site availability, and disease. Of these forces, food availability is often most sensitive to seasonal, annual and decadal variation in climate (Sæther
2000). Thus, climatic variation can be a dominant force structuring avian populations and communities (Sillett et al. 2000). Many species initiate their reproductive activities to coincide with periods of peak prey availability and climatic variation can induce mismatches between the timing of breeding and prey availability, thereby reducing reproductive success (Thomas et al. 
2001). Birds that take prey over large spatial scales, like seabirds, act as environmental samplers, providing information on food web composition, location of prey, and relative abundance of prey among years in relation to changing climatic (oceanographic) conditions (Sydeman et al. 2001).

In marine ecosystems, prey availability for seabirds is affected by oceanographic conditions at both basinwide and local spatial scales (Parrish \& Zador 2003), with local conditions generally being influenced by large-scale processes. In the NE Pacific, and the California Current System (CCS) in particular, basin-scale conditions are dominated by 2 to $7 \mathrm{yr}$ recurrences of warm water El Niño-Southern Oscillation (ENSO) and cool water La Niña events. Basin-scale variation, as measured by Southern Oscillation Index (SOI), Northern Oscillation Index (NOI) and North Pacific Index (NPI), affects both predator and prey species in the CCS. For example, both rockfishes and seabirds exhibit above average reproductive success during cool La Niña years (Ainley et al. 1995, Brodeur et al. 2003). Local-scale conditions, such as sea surface temperature (SST), strength of the spring turnover to cool water conditions, currents, eddies, fronts, vertical mixing and coastal upwelling, occur within the context of these basin-wide patterns. Local-scale conditions typically create regions of increased prey density through physical aggregation or local nutrient enhancement where seabirds can efficiently find adequate prey (Bakun 1996, Becker \& Beissinger 2003). For example, warmer ENSO years often exhibit decreased upwelling and/or upwelling of nutrient poor equatorial waters (Castro et al. 2001), while non-ENSO (cool) years exhibit an increase in upwelling and primary productivity (Chavez et al. 2002). Indices of basin-wide and local-scale conditions typically vary annually with moderate to little interannual autocorrelation.

Larger-scale and longer-term oceanographic variation in the NE Pacific occurs in cycles known as the Pacific Decadal Oscillation (i.e. 'regime shifts'). Unlike local and basin indices, PDO is a highly autocorrelated index, showing 20 to $30 \mathrm{yr}$ periods of persistent positive or negative temperature anomalies. 'Cool' states of the PDO favor seabirds and other marine predators in the CCS (Sydeman et al. 2001). Because of its persistent state, PDO shifts may result in a numerical response (i.e. predator populations increase) due to the bottom-up effects of increasing primary and secondary productivity through nutrient enhancement (Hare \& Mantua 2000). Long-term PDO cycles create long-term shifts in community composition of plankton, prey fishes, predatory fishes, seabirds and marine mammals (Hare \& Mantua 2000). For example, sardine and anchovy populations alternate in dominance with PDO regimes (Chavez et al. 2003). Numerical responses to
PDO appear to occur more rapidly at lower trophic levels, presumably because these organisms have shorter generation times and can respond more rapidly to changes in environmental conditions. Because nonENSO and cool PDO events increase primary productivity in the CCS, they are also correlated with the abundance of microzooplankton (Hare \& Mantua 2000), which are eaten by small fishes and meso- and macrozooplankton. Thus, PDO cycling also affects nutrient delivery to the photic zone and may be viewed as long-term ENSO or non-ENSO conditions.

We investigated the effects of oceanographic variability on prey availability, diet, and reproductive indicators of a federally threatened (USA designation) and state endangered (California) seabird, the marbled murrelet: Brachyramphus marmoratus (Alcidae). The murrelet occurs in the NE Pacific coastal zone from the Bering Sea to central California in both upwelling (California Current) and downwelling (Alaska Current) systems. In central California, the murrelet forages in nearshore waters generally less than $25 \mathrm{~m}$ deep and within $2 \mathrm{~km}$ of shore (Becker \& Beissinger 2003). Murrelet populations have been subjected to severe loss of nesting habitat and subsequent population declines over the past century. In addition, murrelet reproductive success is limited by prey availability in some years (Peery et al. 2004b). Thus, both reproductive success and diet should vary with ocean conditions and subsequent prey availability, as with many other seabirds in this region (Sydeman et al. 1997, Miller \& Sydeman 2004).

Previous studies indicate that murrelets are somewhat euryphagous, taking a wide variety of prey items potentially impacted by seasonal, interannual and interdecadal climatic variation, including mysid shrimp (Mysis spp.), krill Thysanoessa spinifera and Euphausia pacifica, northern anchovy Engraulis mordax, sand lance Ammodytes hexapterus, market squid Loligo opalescens, juvenile rockfishes Sebastes spp., Pacific sardines Sardinops sagax, Pacific herring Clupea harengus and smelt Osmeridae (Sealy 1975, Carter 1984, Burkett 1995). Stable isotope analysis of nitrogen $\left(\delta^{15} \mathrm{~N}\right)$ conducted on marbled murrelet pectoral muscle collected in British Columbia, Canada, suggested that murrelets have an intermediate trophic level among alcids, primarily eating fish, and to a lesser extent, zooplankton (Hobson 1990). However, numerous observations of murrelets holding fish and squid on the water (Carter 1984) and its long, narrow bill imply that murrelets are primarily piscivores and that lower trophic level invertebrates, such as krill, may be only a minor component of their diet. Nestlings are primarily fed fishes and occasionally squid, but are not known to consume krill (Nelson \& Peck 1995). 
Here we investigate how marbled murrelet diet and productivity reflect basin and local-scale oceanographic processes. We construct a local food web using known and potential murrelet prey species, examine annual fluctuation in food availability, and determine how the diet and trophic position of murrelets varies seasonally and annually using stable isotope analyses. Finally, we relate indices of basin- and local-scale conditions (basin-scale SOI, NOI, PDO and NPI; and localscale upwelling, SSTs and spring turnover) to murrelet prey availability, diet composition, and productivity. While this study is primarily an exploratory analysis of these environment-diet-reproduction relationships, we do predict that cooler ocean conditions (which increase primary productivity in this eastern boundary upwelling system) should result in heightened prey availability and hence higher reproductive success for the murrelet.

\section{MATERIALS AND METHODS}

From 1998 to 2002, we studied the diet and reproductive parameters of a semi-isolated population of approximately 487 to 637 marbled murrelets (Peery et al. 2004a). This population nests in the Santa Cruz Mountains, about $30 \mathrm{~km}$ north of Monterey Bay in central California, USA. Population size appears to have been stable since 1996 but may be sustained by immigration from northern populations (Peery et al. 2006).

We used stable isotope analysis of feathers to infer variation in the diet and trophic level of murrelets. We collected whole breast feathers and the tip of a 5th secondary feather from 215 marbled murrelets $(\mathrm{n}=370$ feather samples) caught in Año Nuevo Bay $\left(37.1^{\circ} \mathrm{N}\right.$, $122.3^{\circ} \mathrm{W}$ ) from 1998 to 2002 . Breast feathers are regrown during both the prebreeding and postbreeding molts, while secondaries are only replaced during the pre-basic molt (Carter \& Stein 1995). Thus, browntipped breast feathers represent the prebreeding diet (March to April), and both secondaries and all-white breast feathers represent the postbreeding diet (August to September). For example, secondaries collected in the spring of 1998 represent diet during the 1997 postbreeding molt. Most birds were sexed via microsatellite DNA extracted from blood samples (Peery et al. 2004b).

Prey samples. We obtained potential murrelet prey items for isotopic analysis from 2 sources: shipboard undulating midwater trawls in Año Nuevo Bay, California, and Monterey Bay, California during 2001 and 2002 (courtesy of Moss Landing Marine Laboratories) and from rhinoceros auklets Cerorhinca monocerata bringing prey to chicks at a colony by Año Nuevo Bay during 1996 to 2000 (courtesy of PRBO Conservation
Science). Potential prey obtained included night smelt Spirinchus starskii, northern anchovy, sand lance, market squid, juvenile shortbelly, widow and blue rockfish Sebastes spp., Pacific sardines, krill Euphausia pacifica and Thysanoessa spinifera, white croaker Genyonemus lineatus, mysid shrimp, and Pacific herring. Obtaining stomach samples directly from murrelets would require sacrificing birds or discharging their stomach contents, neither of which were feasible. Collecting samples at nests would only produce prey carried inland and fed to nestlings, and nests are generally inaccessible.

Isotope values for prey species were pooled across years for statistical analyses because we did not have adequate samples of each prey species for all years. However, we did have multiple years of data for northern anchovy (1997 to 2000) and market squid (1997, 2000) and could test for interannual variation for these species.

Laboratory analyses. We subsampled lateral muscle tissue from all fishes, mantles from squid, and whole bodies of the krill and mysids for stable isotope analysis. Prey samples were freeze-dried, subjected to lipid extraction with a methanol:chloroform:water (50:25:20 $\mathrm{v}: \mathrm{v})$ solution for at least $24 \mathrm{~h}$, rinsed with distilled water, and redried (Thompson \& Furness 1995). To remove carbonates, krill were also soaked in $1 \mathrm{~N} \mathrm{HCl} \mathrm{un-}$ til bubbling stopped (Thompson \& Furness 1995).

Feathers were cleaned with a methanol:chloroform: water rinse, rinsed with distilled water, and air-dried. Approximately $1.2 \mathrm{mg}$ of dried feather was loaded into tin capsules and analyzed for $\delta^{15} \mathrm{~N}$ and $\delta^{13} \mathrm{C}$ with a Europa 20/20 continuous-flow isotope-ratio mass spectrometer at the University of California Berkeley Center for Stable Isotope Biogeochemistry. Peach leaves (45\% C, $10.6 \%$ N: National Institute of Standards and Technology, NIST, No. 1577b) and bovine liver (45\% C, $2.96 \%$ N, NIST No. 1547) were used as standards for $\mathrm{C}$ and $\mathrm{N}$, respectively. Standards were analyzed between every 8 feather samples and a leastsquares nonlinear model was used to correct any drift during the analysis. Analytical precision (SD) of analyses was always less than $\pm 0.25 \%$ for $\delta^{15} \mathrm{~N}$ and $\pm 0.10 \%$ for $\delta^{13} \mathrm{C}$. Isotopic ratios are expressed in the del notation (parts per thousand, \%) relative to atmospheric nitrogen (for $\delta^{15} \mathrm{~N}$ ) or Pee Dee belemnite (for $\delta^{13} \mathrm{C}$ ).

Inspection of histograms and probability plots indicated that isotope data were normally distributed, so parametric statistics were used. To facilitate meaningful interpretation of isotope data (Phillips et al. 2005), we used $k$-means clustering to group the potential prey items by reducing within group sums of squares (SPSS 1998). This resulted in 3 groups with statistically similar $\delta^{13} \mathrm{C}$ and $\delta^{15} \mathrm{~N}$ values labeled as low, mid, and high trophic level seabird prey groups. Isotope values 
for all prey species were pooled across years for comparison with murrelet diets.

The krill, Euphausia pacifica and Thysanoessa spinifera, have identical values for $\delta^{13} \mathrm{C}$ and $\delta^{15} \mathrm{~N}$ (Sydeman et al. 1997), so we assumed that any results indicating feeding on $E$. pacifica could equally be $T$. spinifera. This is especially important since the former species is generally oceanic (occurring beyond the shelf-break) and the latter is associated with coastal (over the shelf) upwelling and surface swarming (Smith \& Adams 1988, Ainley et al. 1996a, Adams et al. 2004). Murrelets are confined to the nearshore coastal shelf, and the appearance of $T$. spinifera in the spring is related to the onset of breeding and reproductive success in Cassin's auklets (Ainley et al. 1996a). We, therefore, assumed that $T$. spinifera is a more likely euphausiid prey item for murrelets than E. pacifica.

To estimate the proportion of prey items from each trophic level grouping that murrelets fed upon, we used a diet-feather fractionation value of $3.7 \%$ for $\delta^{15} \mathrm{~N}$ and $1.0 \%$ for $\delta^{13} \mathrm{C}$. This was based on the dietfeather fractionation in common murres (Becker \& Beissinger unpubl. data) and is similar to values published for other seabirds (Thompson \& Furness 1995, Vanderklift \& Ponsard 2003). We used the IsoError dual-isotope, 3-source mixing model (Phillips \& Gregg 2001) to estimate the proportion of low, mid and high trophic level prey (see results for prey species comprising each group) consumed by murrelets during each pre- and postbreeding molt from 1998 to 2002. Because all prey items and bird feathers had similar C:N ratios ( 15:1) we did not use concentration dependent models.

Prey abundance, energetics and oceanography. Results from the National Marine Fisheries Service annual spring rockfish stock assessment cruises were collected for each year from 1995 to 2003 (Brodeur et al. 2003). There were generally 75 to 100 systematically placed trawls done annually during the onset of the murrelet nesting season in May to June at a range of water column depths (5 to $100 \mathrm{~m}$ ) between Monterey Bay $\left(36^{\circ} \mathrm{N}\right)$ and Point Reyes, CA $\left(38^{\circ} \mathrm{N}\right)$ (Data courtesy S. Ralston, NMFS, Santa Cruz). Trawls were as close as $2 \mathrm{~km}$ to shore and ranged to the continental slope (up to $30 \mathrm{~km}$ from shore). A literature search provided energetic content for potential prey items. We also obtained mean monthly Bakun upwelling indices (Bakun 1996 ) at $36^{\circ} \mathrm{N}, 122^{\circ} \mathrm{W}$, monthly NOI, SOI 3.4, NPI, PDO, and SSTs at SE Farallon Island (www.pfeg.noaa. gov) to search for correlations between oceanographic variation, prey abundance, marbled murrelet diet, and indicators of reproduction. ENSO conditions are measured via the Southern Oscillation Index (SOI), which is the normalized difference in sea level pressure (SLP) between Tahiti and Darwin, Australia. Similarly, the
Northern Oscillation Index (NOI) is a function of the difference in SLP between the NE Pacific and Darwin, Australia. Thus, SOI is a measure of equatorial forces traveling poleward up the west coast of North America, and NOI is a measure of how strongly this effect manifests itself locally in the NE Pacific (Schwing et al. 2002). Because basin-scale oceanographic indicators (SOI and NOI) were highly correlated $(\mathrm{r}=0.65$, $\mathrm{p}<0.05)$ throughout the study period, we only used NOI in subsequent analyses, as it provides a more locally derived index of basin-scale conditions. The North Pacific Index (NPI) is another large-scale index that summarizes sea level pressure over the North Pacific. We used the annual and mean values of the first 4 months of each year for these indices, as this period is most important to the onset of reproduction in seabirds due to effects of upwelling on prey abundance (Ainley et al. 1996a,b). Strength of the spring turnover was calculated as the difference in mean daily SSTs between the January to March and April to May periods.

Statistical analyses. We tested for correlations between annual indicators of murrelet productivity (juvenile:adult ratios) (Peery et al. 2004b, in press) with diet and oceanographic variables (SOI, NOI, NPI, PDO, SST, turnover strength and upwelling). Estimates of annual reproductive success were measured as hatch-year to after-hatch-year ratios (HY:AHY) and were obtained from at-sea surveys during the breeding season (Peery et al. in press). Tests of the assumptions for using juvenile ratios indicated that they are appropriate measures for estimating annual variability in productivity and relating productivity to environmental conditions (Peery et al. in press). Statistical tests were done using Systat 8.0 (SPSS 1998) and we considered $p<0.05$ to be statistically significant. However, because these tests use annual estimates with only 5 to 9 yr of samples, in a few instances we discuss results that approach significance $(0.05<\mathrm{p}$ $<0.10$ ) and allow the reader to judge their importance. Results are presented as means \pm 1 standard error or deviation, as indicated.

\section{RESULTS}

\section{Prey species composition, abundance and energetics}

Potential prey isotopic signatures clustered strongly by species and trophic level (Fig. 1A, Table 1). $k$-means clustering grouped 3 distinct trophic groups on the basis of $\delta^{15} \mathrm{~N}$ and $\delta^{13} \mathrm{C}$ values of potential prey (overall clustering model $\chi^{2}{ }_{20}=146.2$, $\mathrm{p}<0.001$; see Table 1 for classification success). Such a priori grouping of dietary sources is useful in dual-isotope models 

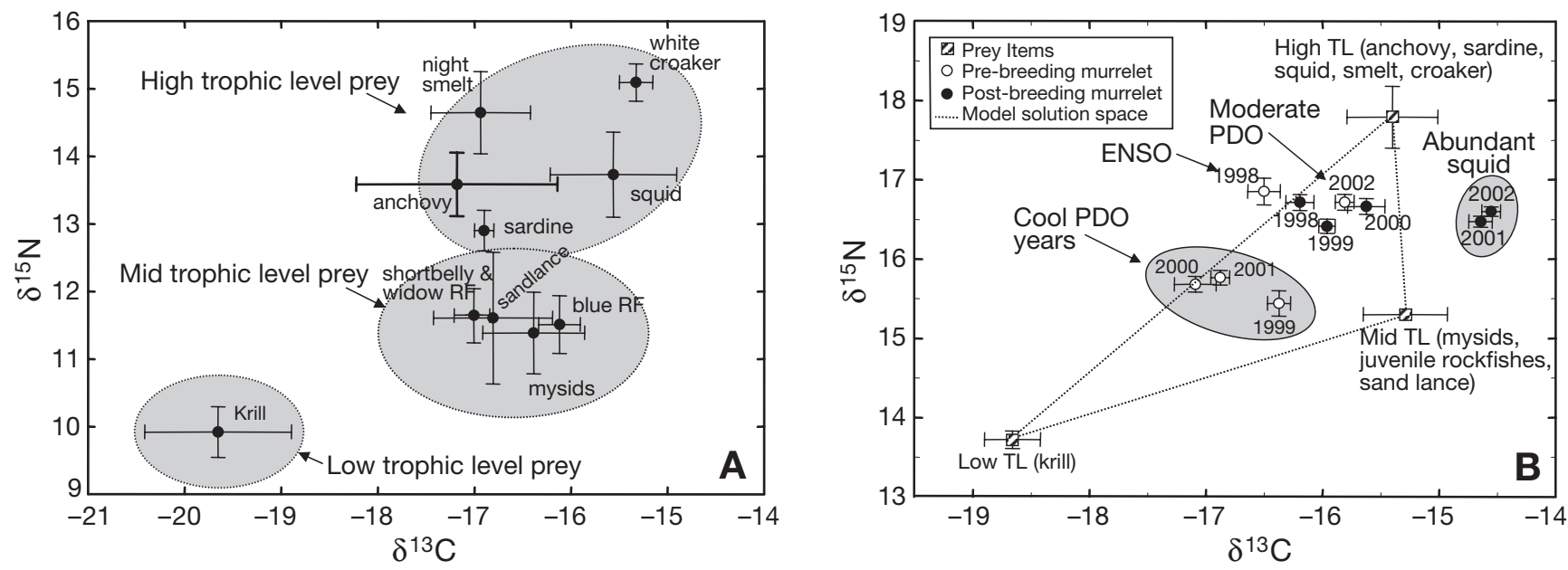

Fig. 1. (A) $\delta^{15} \mathrm{~N}$ and $\delta^{13} \mathrm{C}$ values for potential prey items (of murrelet Brachyramphus marmoratus) collected in central California; low, mid and high trophic levels (TL) based on k-means clustering assignments (Table 1). (B) Prey groupings and pre- and postbreeding marbled murrelet diets from 1998 to 2002. Prey items have been corrected for consumer-prey fractionation $\left(\delta^{15} \mathrm{~N}=\right.$ $3.7 \%, \delta^{13} \mathrm{C}=1.0 \%$ ); area within the dotted line connecting the means of high, mid and low trophic level prey items represents the 3-source isotope mixing model solution space. RF: rockfish. Error bars are SEs

Table 1. Brachyramphus marmoratus. Stable isotope ratios for marbled murrelets and their potential prey items (TL: trophic level). Superscripts indicate statistically similar values within columns (Bonferroni inequality, all p >0.35) but only indicate groupings of either predators or prey. $k$ represents classification success: all 3 rockfish species were tested as a group, we thus report $60 \%$ classification success for each species

\begin{tabular}{|lcccr|}
\hline Species & $\mathrm{n}$ & $\delta^{15} \mathrm{~N}(\%)$ & $\delta^{13} \mathrm{C}(\%)$ & $k(\%)$ \\
\hline Krill Euphausia pacifica & $\mathbf{1 0}$ & $\mathbf{9 . 9} \pm \mathbf{0 . 4}^{\mathrm{a}}$ & $\mathbf{- 1 9 . 7} \pm \mathbf{0 . 8 ^ { \mathrm { a } }}$ & 90 \\
Lower TL fishes and crustacean & & & \\
Mysid shrimp & 9 & $11.4 \pm 0.6^{\mathrm{b}}$ & $-16.4 \pm 0.5^{\mathrm{b}}$ & 100 \\
Blue rockfish & 3 & $11.5 \pm 0.4^{\mathrm{b}}$ & $-16.1 \pm 0.2^{\mathrm{b}}$ & 60 \\
Sand lance & 7 & $11.6 \pm 1.0^{\mathrm{b}}$ & $-16.8 \pm 0.6^{\mathrm{b}}$ & 71 \\
Shortbelly rockfish & 10 & $11.6 \pm 0.6^{\mathrm{b}}$ & $-17.1 \pm 0.3^{\mathrm{ab}}$ & 60 \\
Widow rockfish & 2 & $11.7 \pm 0.4^{\mathrm{b}}$ & $-17.0 \pm 0.1^{\mathrm{b}}$ & 60 \\
Group mean & $\mathbf{5}$ & $\mathbf{1 1 . 5} \pm \mathbf{0 . 1}$ & $\mathbf{- 1 6 . 3} \pm \mathbf{0 . 8}$ & \\
Higher TL fishes and cephalopod & & & \\
Pacific sardine & 3 & $12.9 \pm 0.1^{\mathrm{c}}$ & $-17.0 \pm 0.3^{\mathrm{a}}$ & 100 \\
Northern anchovy & 27 & $13.6 \pm 0.5^{\mathrm{d}}$ & $-17.2 \pm 1.0^{\mathrm{a}}$ & 74 \\
Market squid & 21 & $13.7 \pm 0.6^{\mathrm{d}}$ & $-15.6 \pm 0.7^{\mathrm{b}}$ & 100 \\
Night smelt & 11 & $14.6 \pm 0.6^{\mathrm{e}}$ & $-16.9 \pm 0.5^{\mathrm{c}}$ & 100 \\
White croaker & 10 & $15.1 \pm 0.3^{\mathrm{e}}$ & $-15.3 \pm 0.2^{\mathrm{b}}$ & 100 \\
Group mean & $\mathbf{5}$ & $\mathbf{1 4 . 0} \pm \mathbf{0 . 9}$ & $\mathbf{- 1 6 . 4} \pm \mathbf{0 . 9}$ & \\
Marbled murrelets & & & & \\
1997 post-breed & 5 & $17.2 \pm 0.3^{\mathrm{a}}$ & $-15.8 \pm 0.8^{\mathrm{a}}$ & - \\
1998 pre-breed & 13 & $16.9 \pm 0.6^{\mathrm{a}}$ & $-16.5 \pm 0.5^{\mathrm{ad}}$ & - \\
post-breed & 25 & $16.7 \pm 0.5^{\mathrm{a}}$ & $-16.2 \pm 0.6^{\mathrm{abd}}$ & - \\
1999 pre-breed & 35 & $15.4 \pm 1.0^{\mathrm{b}}$ & $-16.4 \pm 0.6^{\mathrm{ad}}$ & - \\
post-breed & 62 & $16.4 \pm 0.7^{\mathrm{a}}$ & $-16.0 \pm 0.6^{\mathrm{abd}}$ & - \\
2000 pre-breed & 42 & $15.7 \pm 0.6^{\mathrm{b}}$ & $-17.1 \pm 1.2^{\mathrm{d}}$ & - \\
post-breed & 30 & $16.7 \pm 0.5^{\mathrm{a}}$ & $-15.6 \pm 0.9^{\mathrm{ab}}$ & - \\
2001 pre-breed & 36 & $15.8 \pm 0.6^{\mathrm{b}}$ & $-16.9 \pm 0.8^{\mathrm{d}}$ & - \\
post-breed & 40 & $16.5 \pm 0.5^{\mathrm{a}}$ & $-14.6 \pm 0.6^{\mathrm{c}}$ & - \\
2002 pre-breed & 20 & $16.7 \pm 0.7^{\mathrm{a}}$ & $-15.8 \pm 0.5^{\mathrm{abd}}$ & - \\
post-breed & 20 & $16.6 \pm 0.3^{\mathrm{a}}$ & $-14.6 \pm 0.3^{\mathrm{c}}$ & - \\
${ }^{1}$ From Sydeman et al. (1997) & & & & \\
\hline
\end{tabular}

with greater than 3 potential sources to generate interpretable results (Phillips et al. 2005). These 3 groupings (Fig. 1A) were (1) low trophic level prey comprised of 2 species of krill; (2) midtrophic level prey comprised of mysid shrimp, sand lance, and young-of-theyear rockfishes (comprising blue, widow and shortbelly rockfishes); and (3) high trophic level prey comprising sardine, anchovy, night smelt, white croaker, and market squid. The mid trophic level group exhibited little interspecific variation in $\delta^{15} \mathrm{~N}$, and averaged $2.6 \%$ less than high trophic level prey. $\delta^{13} \mathrm{C}$ means, on the other hand, did not differ between the mid and high groups. Variation in isotopic signature was greatest among prey in the high trophic level group. Nevertheless, assignments to trophic levels were robust for all species (Table 1).

Pooling of species across years also appeared to be robust. Although, northern anchovy $\delta^{15} \mathrm{~N}$ values did vary by year $\left(F_{3,23}=7.8, \mathrm{p}<0.001\right)$, this effect was entirely due to 1998 (ENSO) being $0.6 \%$ lower than 1997, 1999, and 2000 (Bonferroni inequality, $\mathrm{p}<0.001$ ). Market squid showed no $\delta^{15} \mathrm{~N}$ difference between 1997 and 2000 (Student's $t=$ $-1.5, \mathrm{df}=18, \mathrm{p}>0.14)$. There was also no correlation between anchovy length 
and $\delta^{15} \mathrm{~N}(\mathrm{r}=0.133, \mathrm{df}=13, \mathrm{p}>0.99)$ or $\delta^{13} \mathrm{C}(\mathrm{r}=0.524$, $\mathrm{df}=13, \mathrm{p}>0.19)$. Further evidence of limited interannual variation in prey species comes from comparison of our results with Sydeman et al. (1997) who also sampled prey items from the same region during 1994 and 1995. Mean differences among our samples and those reported in Sydeman et al. (1997), for $\delta^{15} \mathrm{~N}$ and $\delta^{13} \mathrm{C}$, respectively, were anchovy 0.3 and $0.4 \%$; krill 1.3 and $0.5 \%$, and squid 1.4 and $1.5 \%$. Furthermore, more recent isotope values of sardines indicate that our values are in agreement with those currently found in California current (R. Vetter \& D. Field pers. comm.).

Abundance of potential prey species differed greatly by trophic level (Fig. 2) and appeared to be affected by oceanographic variation (Table 2). Krill, the most

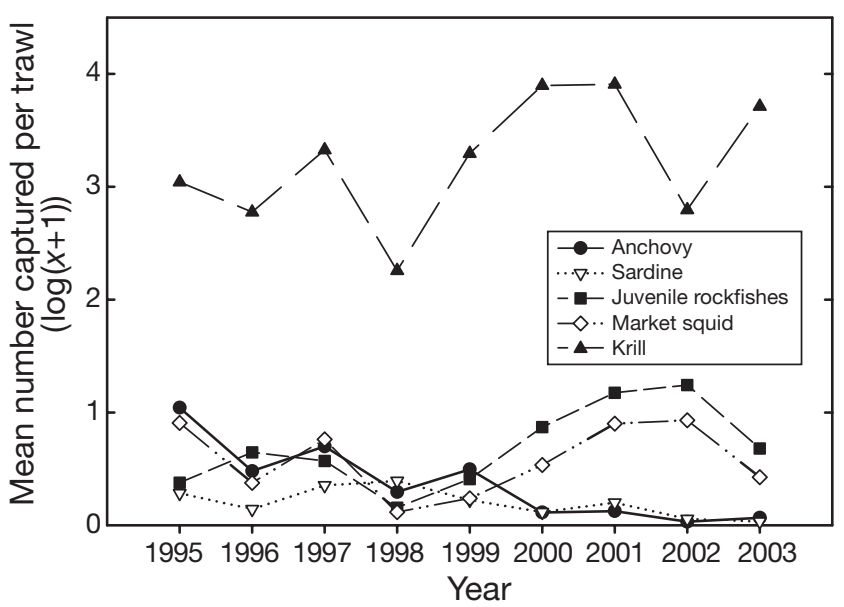

Fig. 2. Log-transformed mean counts from trawls for potential seabird prey items off the coast of central California during late May and early June, 1995 to 2003 (Raw data courtesy of the National Marine Fisheries Service, Santa Cruz, California) abundant prey, were least abundant during the warm PDO years of 1998 and 2002. Sardine and anchovy abundance was less variable throughout the study period, but anchovies peaked during the 1999 La Niña and declined thereafter. The limited number of years of study precluded robust correlations of prey abundance with oceanographic conditions (Table 2). Nevertheless, basin-scale NOI approached significance with rockfish abundance ( $\mathrm{p}<0.1)$, but regional PDO and local UI indices were not associated with prey abundance. Similar patterns of prey abundance by year were reported by Brodeur et al. (2003) for the same region.

Energetic value varied greatly among potential prey species of murrelets, but in general, higher trophic level species had greater per capita caloric value (Table 3). Pacific sardines contained the greatest caloric value, and krill were the least valuable. Juvenile rockfish and market squid had about one-third to one-fourth the energetic value of a sardine prey item, while $\mathrm{kJ}$ per food item was $60 \%$ less for anchovies. To gain the same energetic value as eating an anchovy, a murrelet would need to consume $\sim 45$ low trophic level prey items and $\sim 2-12$ mid-trophic level items (Table 3). Similarly, for the even more energy rich sardine, this ratio increases to $\sim 74-80$ krill and 3-20 mid-trophic level prey items. Encounter rates and handling times would have to differ greatly among species to overcome trophic level differences in profitability caused by energetic values.

\section{Annual and seasonal changes in the diet and productivity of marbled murrelets}

Murrelet diet composition generally fell within the boundaries imposed by potential diet sources (Fig. 1B)

Table 2. Pearson correlations between mean January to April oceanographic variables, spring prey abundance, and marbled murrelet Brachyramphus marmoratus productivity for the years 1995 to $2003(\mathrm{n}=9)$. NOI = Northern Oscillation Index, PDO = Pacific Decadal Oscillation, NPI = North Pacific Index, UI = Upwelling Index, $\mathrm{SST}_{4}=$ sea surface temperature during January to April, $\mathrm{SST}_{\mathrm{AMJ}}=$ sea surface temperature during April to June, Spring turnover $=$ strength of the spring turnover. ${ }^{*} \mathrm{p}<0.05$

\begin{tabular}{|c|c|c|c|c|c|c|c|c|c|c|c|c|}
\hline & $\mathrm{NOI}_{4}$ & $\mathrm{PDO}_{4}$ & $\mathrm{NPI}_{4}$ & $\mathrm{UI}_{4}$ & $\mathrm{SST}_{4}$ & $\mathrm{SST}_{\mathrm{AMJ}}$ & $\begin{array}{l}\text { Spring } \\
\text { turnover }\end{array}$ & $\begin{array}{c}\text { An- } \\
\text { chovy }\end{array}$ & $\begin{array}{l}\text { Sar- } \\
\text { dine }\end{array}$ & Squid & $\begin{array}{l}\text { Rock- } \\
\text { fish }\end{array}$ & Krill \\
\hline $\mathrm{PDO}_{4}$ & -0.62 & - & & & & & & & & & & \\
\hline $\mathrm{NPI}_{4}$ & $0.74^{*}$ & $-0.76^{*}$ & - & & & & & & & & & \\
\hline $\mathrm{UI}_{4}$ & 0.61 & -0.15 & 0.32 & - & & & & & & & & \\
\hline $\mathrm{SST}_{4}$ & $-0.94^{*}$ & $0.77^{*}$ & $-0.73^{*}$ & $-0.75^{*}$ & - & & & & & & & \\
\hline $\mathrm{SST}_{\mathrm{AMJ}}$ & $-0.86^{*}$ & $0.68^{*}$ & $-0.77^{*}$ & -0.49 & $0.89^{*}$ & - & & & & & & \\
\hline Spring turnover & -0.60 & 0.60 & -0.31 & -0.62 & 0.65 & 0.26 & - & & & & & \\
\hline Anchovy & -0.33 & 0.08 & -0.22 & 0.20 & 0.20 & 0.10 & 0.38 & - & & & & \\
\hline Sardine & -0.40 & 0.24 & -0.56 & 0.35 & 0.29 & 0.48 & 0.02 & 0.61 & - & & & \\
\hline Squid & 0.24 & -0.39 & 0.45 & 0.24 & -0.33 & -0.23 & -0.23 & 0.13 & -0.17 & - & & \\
\hline Rockfish & 0.61 & -0.47 & 0.66 & 0.07 & -0.53 & -0.45 & -0.46 & -0.61 & $-0.67^{*}$ & 0.64 & - & \\
\hline Krill & 0.48 & -0.32 & 0.15 & 0.21 & -0.56 & -0.57 & -0.29 & -0.26 & -0.41 & 0.31 & 0.47 & - \\
\hline Murrelet productivity & 0.60 & -0.34 & 0.49 & 0.24 & -0.61 & -0.56 & -0.37 & -0.63 & -0.59 & 0.46 & $0.79^{*}$ & $0.73^{*}$ \\
\hline
\end{tabular}


Table 3. Energetic values for average-sized potential prey items of murrelet Brachyramphus marmoratus. The anchovy equivalent column represents the number of average-sized prey items that would equal the energetic content of an average-sized anchovy. Mean prey sizes from Carter (1984) and Sealy (1975), length-mass regression equations from Spear (1993) and D. G. Ainley (unpubl.)

\begin{tabular}{|c|c|c|c|c|c|c|c|c|}
\hline $\begin{array}{l}\text { Trophic } \\
\text { level }\end{array}$ & Species & Location & $\begin{array}{c}\mathrm{kJ} \mathrm{g}^{-1} \\
\text { (dry) }\end{array}$ & $\begin{array}{l}\mathrm{kJ} \mathrm{g}^{-1} \\
\text { (wet) }\end{array}$ & $\begin{array}{c}\text { Length } \\
\text { (mm) }\end{array}$ & $\begin{array}{l}\text { Wet mass } \\
\quad(\mathrm{g})\end{array}$ & kJ/item & $\begin{array}{l}\text { Anchovy } \\
\text { equivalent }\end{array}$ \\
\hline \multirow[t]{2}{*}{ Low } & Euphausia superba ${ }^{\mathrm{a}}$ & Scotland & 20.8 & 4.7 & $16-20$ & $0.11^{\mathrm{e}}$ & 0.52 & 48.2 \\
\hline & Thysanoessa spp. ${ }^{\mathrm{b}}$ & North Atlantic & 23.8 & - & 24 & $0.12^{\mathrm{e}}$ & 0.56 & 44.8 \\
\hline \multirow{2}{*}{ Mid } & Shortbelly rockfish & Farallones, CA & 21.8 & 4.9 & 60 & 2.51 & 12.30 & 2.0 \\
\hline & Sand lance ${ }^{c}$ & Alaska & 22.0 & - & 60 & - & 2.00 & 12.5 \\
\hline \multirow[t]{4}{*}{ High } & Market squid & Farallones, CA & 20.9 & 4.1 & 40 & 2.44 & 10.02 & 2.5 \\
\hline & Night smelt & Farallones, CA & 19.8 & 4.3 & 60 & 1.84 & 7.91 & 3.2 \\
\hline & Northern anchovy & Farallones, CA & 26.7 & 9.6 & 60 & 2.61 & 25.07 & 1.0 \\
\hline & Pacific sardine ${ }^{\mathrm{d}}$ & California & - & 15.8 & 60 & - & 41.36 & 0.6 \\
\hline \multicolumn{9}{|c|}{ acClarke \& Prince (1980) } \\
\hline \multicolumn{9}{|c|}{ bMartensson et al. (1994) } \\
\hline \multicolumn{9}{|c|}{${ }^{\mathrm{c} P i a t t}(1990)$} \\
\hline \multicolumn{9}{|c|}{${ }^{\mathrm{d}}$ Sardine value $=65 \%$ more $\mathrm{kJ} \mathrm{g}^{-1}$ (wet) than anchovy (Sidwell 1981) } \\
\hline
\end{tabular}

except for 3 of the 10 season-year periods, which fell slightly outside the potential dietary solution area. This is reasonable to expect because extensive feeding on a single species that was particularly enriched in ${ }^{13} \mathrm{C}$ (e.g. squid) within the mid or high trophic level groups could skew predator isotope values away from the mean value of each of the 3 prey groups we used for the calculations. Although it is also possible that murrelets fed on prey not represented in our model, most models found tenable solutions which suggests this was not the case. $\delta^{13} \mathrm{C}$ in postbreeding murrelet diets was highest during 2001 and 2002 (Fig. 1B), which was concurrent with high squid abundance during the postbreeding period in these years (Fig. 2). For the 3 periods that fell outside the diet source boundaries (spring 1998, fall 2001, and fall 2002), we normalized the remaining 2 positive diet proportions to 1 .

Isotopic composition varied greatly between seasons and among years but showed 2 important patterns. During cool water years, murrelet $\delta^{15} \mathrm{~N}$ was typically at a lower trophic level during the prebreeding period and at a higher trophic level during the postbreeding period (Fig. 3A). The warmer PDO years of 1998 and 2002 were exceptions to this pattern, with similar preand postbreeding diets. $\delta^{13} \mathrm{C}$ always shifted higher during the postbreeding season, although this was more pronounced from 2000 to 2002 (Fig. 3B). An ANOVA model including the subset of feather samples from birds that were sexed $(n=134)$ during 1998 to 2001 found that season and the Season $\times$ Year interaction had significant effects on $\delta^{15} \mathrm{~N}$, while Year was marginally significant (Table 4). Carbon isotope ratios also varied by season, year, and the interaction (Table 4). Diet did not differ by sex for either isotope. Results
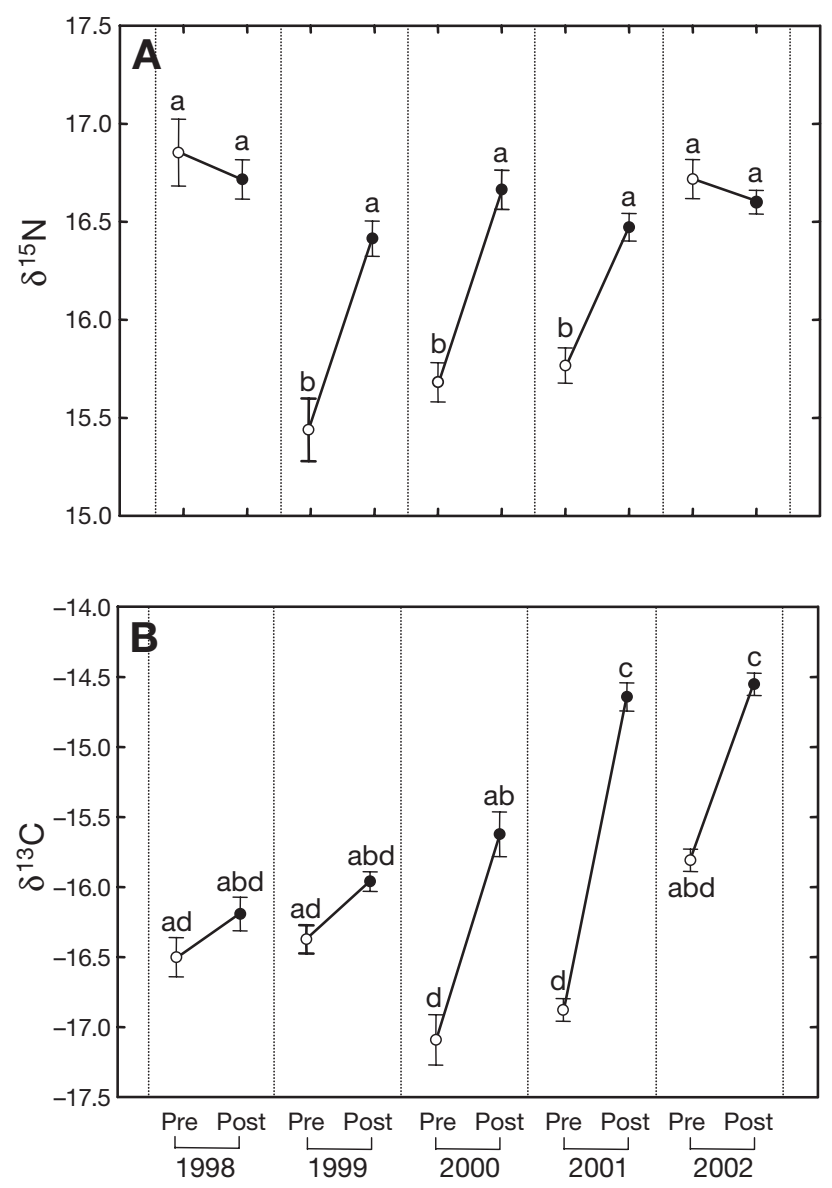

Fig. 3. Brachyramphus marmoratus. Marbled murrelet feather isotope values for (A) $\delta^{15} \mathrm{~N}$ and (B) $\delta^{13} \mathrm{C}$ during the pre(spring) and post- (fall) breeding seasons from 1998 to 2002. Different letters in each panel indicate statistically different values (see Table 1) 
Table 4. Brachyramphus marmoratus. ANOVA testing effects of sex, season, year, and interactions on murrelet isotope ratios. Bold: $\mathrm{p}<0.05$

\begin{tabular}{|c|c|c|c|c|c|}
\hline Factor & SS & $\mathrm{df}$ & MS & $F$ & $\mathrm{p}<$ \\
\hline \multicolumn{6}{|l|}{$\delta^{15} \mathrm{~N}\left(\mathrm{r}^{2}=0.34\right)$} \\
\hline Sex & 0.50 & 1 & 0.51 & 1.36 & 0.244 \\
\hline Season & 3.20 & 1 & 3.20 & 8.65 & 0.004 \\
\hline Year & 3.00 & 4 & 0.74 & 2.01 & 0.094 \\
\hline Season $\times$ Year & 4.43 & 4 & 1.11 & 3.00 & 0.020 \\
\hline Season $\times$ Sex & 0.04 & 1 & 0.04 & 0.11 & 0.736 \\
\hline Year $\times$ Sex & 3.00 & 4 & 0.75 & 2.02 & 0.092 \\
\hline Season $\times$ Sex $\times$ Year & 2.32 & 4 & 0.58 & 1.57 & 0.185 \\
\hline Error & 82.20 & 222 & 0.37 & & \\
\hline \multicolumn{6}{|l|}{$\delta^{13} \mathrm{C}\left(\mathrm{r}^{2}=0.57\right)$} \\
\hline Sex & 0.64 & 1 & 0.64 & 1.05 & 0.306 \\
\hline Season & 28.14 & 1 & 28.14 & 46.64 & 0.001 \\
\hline Year & 23.10 & 4 & 5.77 & 9.57 & 0.001 \\
\hline Season $\times$ Year & 31.37 & 4 & 7.84 & 13.00 & 0.001 \\
\hline Season $\times$ Sex & 0.53 & 1 & 0.53 & 0.88 & 0.349 \\
\hline Year $\times$ Sex & 2.92 & 4 & 0.73 & 1.21 & 0.308 \\
\hline Season $\times$ Sex $\times$ Year & 1.35 & 4 & 0.34 & 0.56 & 0.692 \\
\hline Error & 133.92 & 222 & 0.60 & & \\
\hline
\end{tabular}

from the dual-isotope, 3-source mixing model supported these trends and indicated that the relative consumption of trophic levels by murrelets varied greatly both annually and seasonally. High trophic level prey was always consumed, but in some years either low or mid trophic level prey disappeared completely from the diet (Fig. 4).

Diet and productivity of murrelets were related. In years when krill were more abundant, prebreeding $\delta^{15} \mathrm{~N}$ tended to be lower (Fig. 5A). Similarly, when the ${ }^{13} \mathrm{C}$ enriched juvenile rockfish and squid were

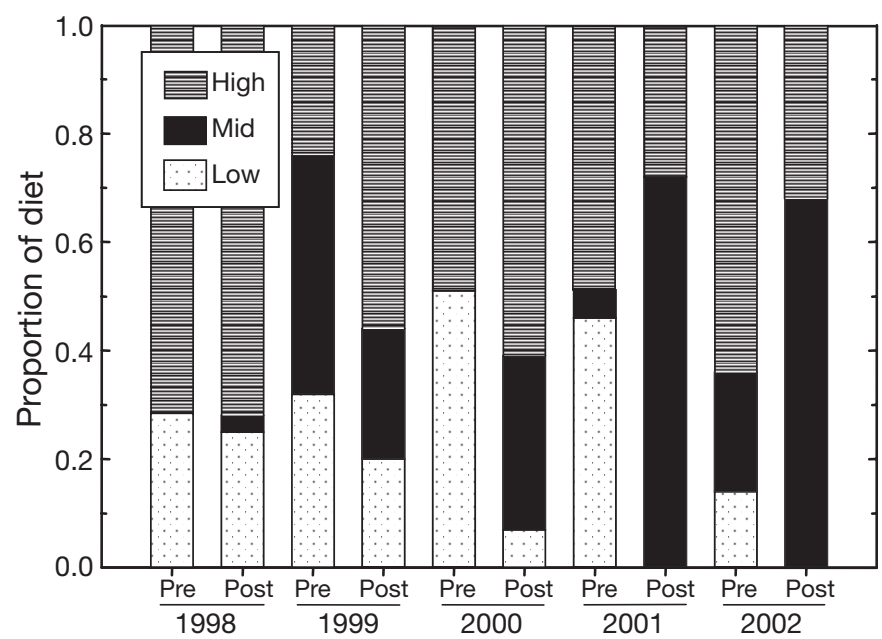

Fig. 4. Brachyramphus marmoratus. Results of dual-isotope, 3-source mixing model specifying average murrelet dietary inputs from low, mid and high trophic level prey during preand postbreeding seasons from 1998 to 2002. SEs were all between 0.03 and 0.09 more abundant, murrelet postbreeding $\delta^{13} \mathrm{C}$ increased (Fig. 5B,C). Murrelet productivity tended to be positively related with both basin-scale NOI and cooler local SST, and was higher during cool water years, although this relationship was not significant $(\mathrm{p}<0.09$; Table 2, Fig. 6A). Furthermore, productivity was positively correlated with both krill and rockfish abundance (Fig. 6B,C). Finally, murrelet productivity was positively related to the proportion of mid-trophic level prey in postbreeding diets, and was negatively related to the proportion of both low and high trophic level prey consumed (Fig. 6D). The only prey items related to ocean conditions, were juvenile rockfishes, which were marginally associated with both cool NOI and NPI conditions ( $p<0.10$; Table 2).

\section{DISCUSSION}

\section{Diet and trophic level}

Isotopic signatures suggest marbled murrelets in central California consume low and mid-trophic level prey items (i.e. krill, juvenile rockfish, sand lance, and mysids), as well as high trophic prey level items (i.e. anchovy, sardine, squid, croaker, and smelt). While these results compare well with Hobson's (1990) placement of murrelets as a mid-trophic level predator, we also found significant seasonal and annual variation in diet. Furthermore, similar to common murres in the California Current (Ainley et al. 1995, 1996b, Miller \& Sydeman 2004), murrelet diets tracked prey availability mediated by climatic forcing. During cool water years when krill were more abundant (1999-2001), murrelets fed at a lower trophic level prior to breeding compared to after the breeding season (Figs. 1B \& 3). However, pre- and postbreeding diets were similar during the warm water year of 1998 and the cool year of 2002. In 1998, krill were less abundant, as were squid and juvenile rockfish, while higher trophic level sardines and anchovies were relatively more common. Similarly, in 2002, krill numbers were also depressed and murrelet spring trophic level failed to show the low trophic level diet signature. Then, in the fall of both 2001 and 2002, when squid were at their greatest abundance during the study period, murrelet diets reflected this with an increase in $\delta^{13} \mathrm{C}$ that would be expected if they had fed greatly on squid. Thus, we conclude that murrelets are robust environmental samplers whose diet reflects changes in prey availability in the California Current under a wide variety of ocean conditions and seasons.

Isotope values reported here appear to be robust measures of murrelet diet and were not due to oceanographic effects on baseline isotope values or physio- 

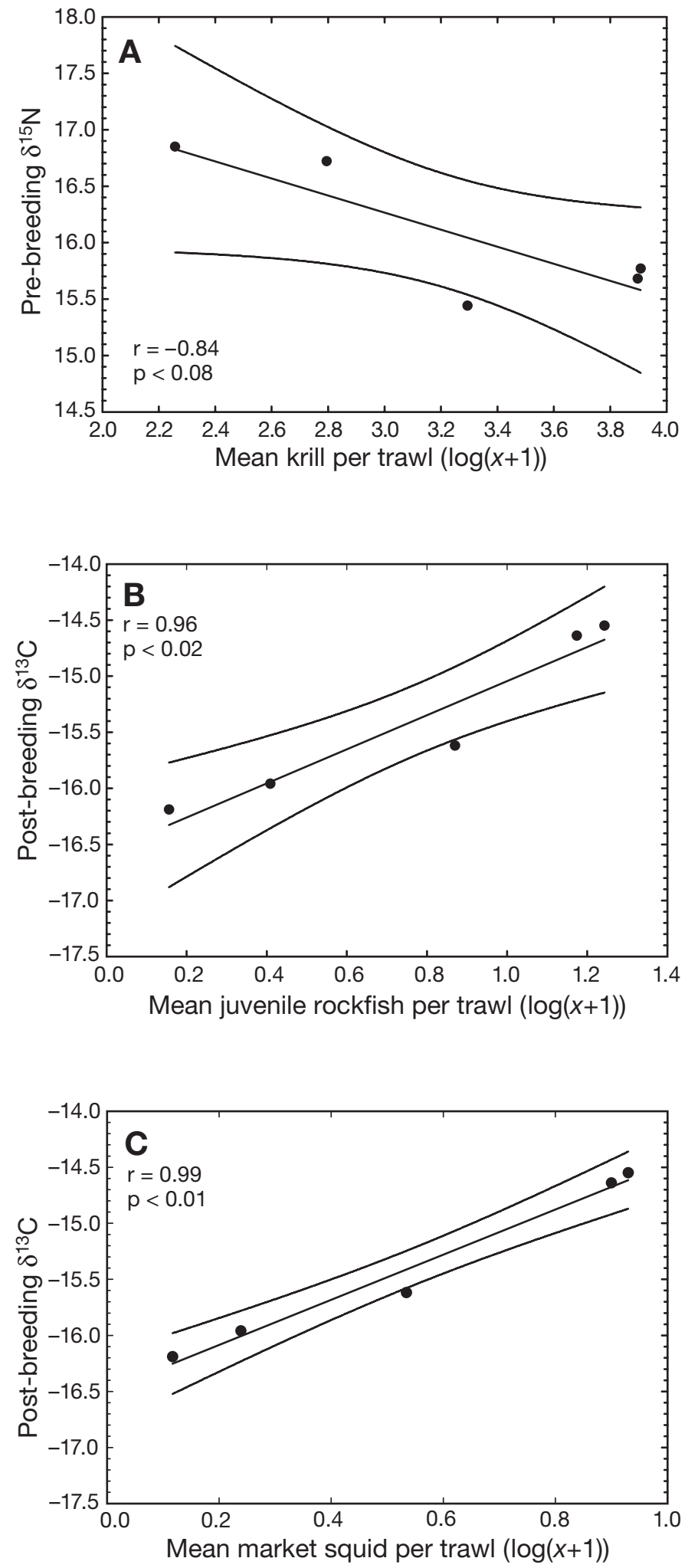

Fig. 5. Brachyramphus marmoratus. Relationship between (A) krill abundance and murrelet prebreeding $\delta^{15} \mathrm{~N}$, (B) juvenile rockfish abundance and postbreeding $\delta^{13} \mathrm{C}$, and (C) squid abundance and postbreeding $\delta^{13} \mathrm{C}$. Regression lines and 95\% confidence intervals are shown logical variation in the birds (Rau et al. 2003, Vanderklift \& Ponsard 2003). $\delta^{15} \mathrm{~N}$ in zooplankton changed little from 1951 to 2001 in the Monterey Bay region (Rau et al. 2003), although there were small, temporary increases $(\sim 1 \%)$ during the strong ENSO years of 1958, 1983, and 1998. Rau et al. (2003) found a similar $\left(\sim 1 \%\right.$ o $\left.\delta^{15} \mathrm{~N}\right)$ PDO effect on 2 species of chaetognath (arrow worm) zooplankton during the 1979 to 1998 warm PDO regime, compared to the preceding and following cool regimes. Annual variation in $\delta^{15} \mathrm{~N}$ enrichment could affect both pre- and postbreeding diets. However, postbreeding diets showed remarkably little annual change in $\delta^{15} \mathrm{~N}$, suggesting both stability in background isotope values and a reduction in low trophic level prey consumed after breeding constraints were relaxed. Furthermore, while fasting could increase $\delta^{15} \mathrm{~N}$, there is no evidence that murrelets fast prior to or during the molt. In fact, they typically gain mass during the fall molt (M. Z. Peery unpubl. data). Thus, isotopic signals revealed in this study are likely to represent actual variation in diet composition.

The $\sim 1$ to $2 \%$ lower $\delta^{13} \mathrm{C}$ values recorded during the springs of 1999 to 2001 suggest that krill had been ingested in significant amounts. To produce the observed isotopic signatures had murrelets been feeding solely on mid- and high trophic level items, $\delta^{13} \mathrm{C}$ fractionation in feathers would have to be between 0 and $-1 \%$, which is highly unlikely (Hobson et al. 1994). The presence of krill (as evidenced by the low $\delta^{15} \mathrm{~N}$ and $\delta^{13} \mathrm{C}$ values) in murrelet prebreeding diets during 1999 to 2001 was somewhat surprising because krill are generally described as inhabiting deep water $(\sim 100 \mathrm{~m})$ during the day (Marinovic et al. 2002) and to surface at night when murrelets do not forage (M. Z. Peery et al. unpubl. data). During spring, however, krill, especially Thysanoessa spinifera, often form surface swarms that are exploited by seabirds during the day (Smith \& Adams 1988, Ainley et al. 1996a). Coincidently, surface swarms of krill (Euphausia pacifica) were found within $1.5 \mathrm{~km}$ of shore in Año Nuevo Bay during June 2003 (D. G. Ainley pers. comm.), which is where most of the birds in this paper were captured and foraged. Furthermore, krill are routinely caught at trawl stations over the continental shelf at both 2 and $5 \mathrm{~km}$ from shore in moderate quantities in central California (S. Ralston unpubl. data). Thus, there appears to be ample opportunity for murrelets to capture krill, and the onset of krill swarming coincides with the prebreeding signature of krill found in murrelet diets (Fig. 1B).

A variety of species comprised mid-trophic level prey for murrelets. Juvenile rockfish, which are important to breeding seabirds on the Farallon Islands, California, also may be important to reproduction for the nearshore feeding marbled murrelet (Fig. 1B). Juvenile rockfish and squid should be available to murrelets 
since they occur nearshore in densities comparable to the Farallones (Brodeur et al. 2003), and are especially aggregated at nearshore fronts (Bjorkstedt et al. 2002). Mysid shrimp may also comprise a significant portion of the murrelet diet during cool water years and they were present in Año Nuevo Bay where murrelets foraged (Henkel \& Harvey 2006). However, due to the absence of time series data for mysids, changes in their abundance cannot be examined in relation to changes in murrelet isotopic signatures and productivity. Similarly, sandlance use these nearshore sandy habitats and may be an important mid-trophic level component of the murrelet's diet. Alternatively, the relationship between mid-trophic level prey and murrelet reproduction may simply be due to favorable conditions for both. However, since we show a sequential relationship between prey availability, diet, and reproductive success, we suspect the relationship is mechanistic and not spurious.

Juvenile rockfishes in murrelet postbreeding diets also closely followed those found in common murre Uria aalge prey delivered to chicks on the Farallon Islands during 1998 to 2002 (Miller \& Sydeman 2004). Common murre chick meals had low percentages of juvenile rockfishes during 1998 to $2000(<10 \%)$, but rapidly increased to $\sim 50-75 \%$ during 2001 and 2002. However, Common Murres did not increase delivery of squid to chicks in 2001 and 2002 (Miller \& Sydeman 2004), when this signal appeared in murrelet diets (Fig. 4). Thus, while we suggest that enriched $\delta^{13} \mathrm{C}$ was an indication of a diet rich in squid during the postbreeding seasons of 2001 and 2002, this interpretation could be erroneous.

Whatever the exact species of mid-trophic level prey that murrelets were taking, it appears that mid-trophic level prey are an important food item for successful reproduction. Murrelet reproductive success was strongly correlated with mid-trophic level prey abundance (Fig. 6C) and with their prevalence in the murrelet's postbreeding diet (Fig. 6D). This relationship may have emerged because mid-trophic level prey (1) sustain adults while they tend nests, (2) are fed directly to nestlings, or (3) are eaten by young after they fledge.
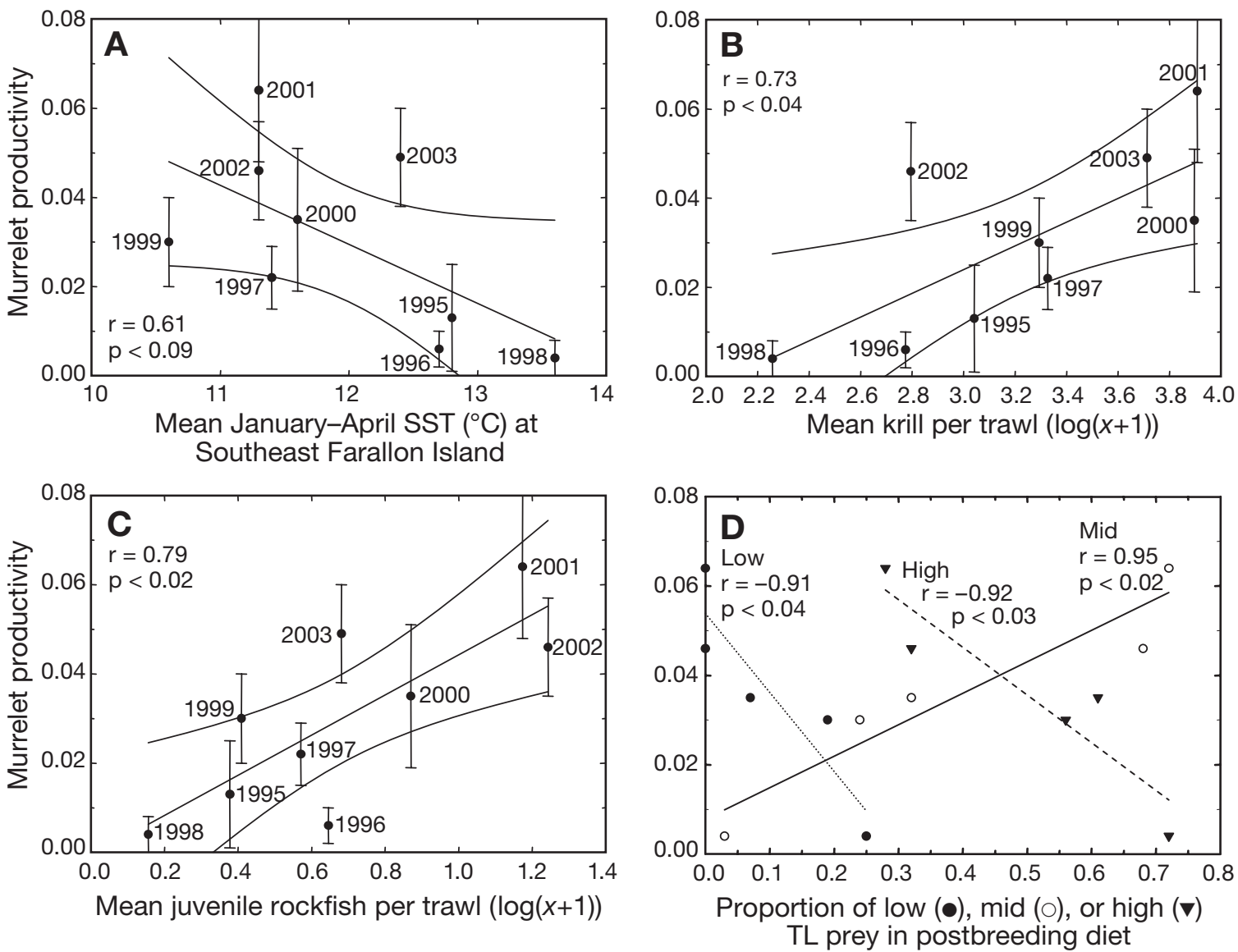

Fig. 6. Brachyramphus marmoratus. Relationship between annual reproductive success or productivity (mean date-corrected ratio of juveniles to after-hatch-year birds) and (A) the SSTs at Southeast Farallon Island, (B) krill abundance during 1995 to 2003 , (C) young-of-the-year juvenile rockfish abundance from 1995 to 2003, and (D) low, mid and high trophic level prey in postbreeding murrelet diets. Krill and rockfish values are from spring shipboard trawls off central California. Regression lines are shown in all panels, with $95 \%$ confidence intervals in (A) to (C) 
Moreover, both prebreeding and postbreeding prey availability and diet composition appear to be important to murrelets for successful reproduction (Fig. 6).

Mid-trophic level species and krill and were important components of murrelet prebreeding diets despite overfishing of several species of rockfishes in central California (Leet et al. 2001, Starr et al. 2002) and an apparent decline in zooplankton in the CCS over the past 50 yr (McGowan et al. 1998, Lavaniegos \& Ohman 2003). The relationships between mid-trophic level prey dynamics and murrelet diets and reproduction, and the representation of low trophic level prey in murrelet diets could both be due to the concurrent decline in the availability of higher trophic level prey, such as sardines and anchovies due to fishing pressure (Leet et al. 2001) and to natural ecosystem variability such as PDO cycles (Chavez et al. 2003). Contemporary marine food webs around the world and in the California Current are highly modified compared to food webs prior to heavy fishing pressure (Jackson et al. 2001). The relative contributions of natural and anthropogenic factors on marbled murrelet prey are currently unclear. Nevertheless, modern murrelets feed at a lower trophic level during the prebreeding season than they did a century ago (Becker \& Beissinger 2006).

\section{Oceanographic effects on trophic level and reproductive success}

Seabirds commonly track and consume the most abundant or energetically valuable prey items as they vary seasonally and annually due to oceanographic forcing (Ainley et al. 1995, 1996a,b, Litzow et al. 2002). Our results indicate that a similar pattern occurs for the nearshore-foraging marbled murrelet, however, the direct correlations with climate were weaker. Nevertheless, climatic variability still appeared to affect prey availability, murrelet dietary composition and, as a result, murrelet reproductive success. These relationships, while correlative, are strongly linked by the isotopic evidence showing murrelets do shift their diets in response to availability. Thus, murrelets appear to act as robust environmental samplers that track the availability of prey nearshore, which fluctuates in the CCS primarily due to the influences of climate.

Contrary to our predictions, neither basin nor localscale conditions (NOI and SST, respectively) appeared to dominate murrelet prey availability, even though correlations approached significance with rockfish counts, and both cool NOI and SST were nearly significantly related to higher murrelet reproductive success. Local-scale conditions are driven by basin-scale processes, but basin-scale conditions may manifest themselves differently at local scales each year. For ex- ample, a true ENSO event in the equatorial Pacific is characterized by a low SOI, that generally, but not always, produces a low NOI value in the NE Pacific. This in turn generally leads to above average SSTs and reduced upwelling in the CCS. However, this basin to local-scale relationship is not ironclad: above average SSTs also occur in the absence of ENSO events. Subsequently, similar to Ainley et al.'s (1995) findings with other species of seabirds in the CCS, we consider basin-scale oceanographic conditions as the driving components of murrelet prey availability, diet, and reproductive success, with local conditions both acting as an artifact of and modulating the influence of largescale climate. Although PDO and NPI values did not correlate with murrelet ecology in this study, both indices were related to local SSTs, and PDO was also correlated with spring turnover strength. Thus, long-term, large-scale phenomena are likely to affect murrelet biology in complex ways that may have not been detected in this study.

A regime shift to cooler ocean conditions may have occurred following the 1997 to 1998 ENSO event for the California Current (Chavez et al. 2003), although this assessment is debatable since the PDO has not unequivocally shifted to cool conditions (Overland et al. 2004, Rodionov 2004). However, marbled murrelet productivity did markedly improve beginning in 1999, with all years prior to 1995 to 1998 having lower reproductive success than 1999 to 2003 (Figs 6A-C). We suggest that cooler, more productive ocean conditions probably made more mid-trophic level prey available to murrelets, which improved reproductive success between 1999 and 2003.

Our results suggest the potential impacts of a progressively warmer marine climate induced by global climate change, which may enter a 'semi-permanent' warm phase PDO or ENSO-like state (McGowan et al. 1998, Sydeman et al. 2001), would be likely to reduce murrelet reproductive success. When combined with the effects of overfishing on marine food webs and seabird diets (Pauly et al. 1998, Becker \& Beissinger 2006), global climate change may further exacerbate deteriorating feeding conditions for marine predators such as marbled murrelets. The destruction and fragmentation of the coastal old growth forests has focused conservation concerns on forest habitats that marbled murrelet use for nesting, with little attention to the affects of marine resources on population dynamics and persistence. Nevertheless, the kinds and degrees of impact of climate change on terrestrial and freshwater food webs and ecological linkages (Winder \& Schindler 2004) will probably also be manifested in marine seabirds like the marbled murrelet that must compete with fisheries for prey resources whose abundance and availability are climatically mediated. 
Acknowledgements. We thank S. Newman, S. Sovndal, J. Sovndal, J. Holley, J. Lanser, M. Westphal, S. Hancock, L. Rachowicz, M. Cobleigh, K. Stevenson, J. Benson, N. Jones, R. Seymour, L. Grenier, B. Sandercock, R.C. Mitchell, T. Hausdoerffer, K. Kramer, S. Cooper, J. Meyer, C. Morrison, C. Trauernicht, J. McEntee, E. Burkett, and H. Carter for aid in collecting feather samples and at-sea surveys. P. Brooks and S. Mambelli (UC Berkeley Center for Stable Isotope Biogeochemistry) provided aid with the stable isotope analyses. Prey samples were provided by J. Thayer, W. Sydeman and K. Mills (PRBO Conservation Science); and L. Henkel, J. Adams and A. Toporoff (Moss Landing Marine Laboratory). Logistical support was provided by the California Department of Fish and Game, Office of Spill Prevention and Response and Wildlife Management Divisions (J. Ames, L. Espinoza, E. Burkett, T. Williamson, R. Pucinelli, B. Delano and the crew of the P/B 'Bluefin'), Año Nuevo State Reserve (G. Strachan), and Big Creek Lumber Company (B. McCrary and the Bulger family). S. Ralston (NMFS, Santa Cruz) kindly provided the central California spring trawl data. Analyses and fieldwork were funded by the David and Lucile Packard Foundation, UC Berkeley, the American Museum of Natural History, and the Cooper Ornithological Society. Earlier versions of this manuscript were reviewed by D. Ainley, R. Barrett, M. Kelly, D. Penry, and several anonymous reviewers.

\section{LITERATURE CITED}

Adams J, Takekawa JY, Carter HR (2004) Stable foraging areas and variable chick diet in Cassin's auklets (Ptychoramphus aleuticus) off southern California. Can J Zool 82: 1578-1595

Ainley DG, Sydeman WJ, Norton J (1995) Upper trophic level predators indicate interannual negative and positive anomalies in the California Current food web. Mar Ecol Prog Ser 118:69-79

Ainley DG, Spear LB, Allen SG (1996a) Variation in the diet of Cassin's auklet reveals spatial, seasonal, and decadal occurrence patterns of euphausiids off California, USA. Mar Ecol Prog Ser 137:1-10

Ainley DG, Spear LB, Allen SG, Ribic CA (1996b) Temporal and spatial patterns in the diet of the common murre in California waters. Condor 98:691-705

Bakun A (1996) Patterns in the ocean: ocean processes and marine population dynamics. California Sea Grant College System, NOAA, La Jolla, CA

Becker BH, Beissinger SR (2003) Scale-dependent habitat selection by a nearshore seabird, the marbled murrelet, in a highly dynamic upwelling system. Mar Ecol Prog Ser 256:243-255

Becker BH, Beissinger SR (2006) Centennial decline in the trophic level of an endangered seabird after fisheries decline. Conserv Biol 20:470-479

Bjorkstedt EP, Rosenfeld LK, Grantham BA, Shkedy Y, Roughgarden J (2002) Distributions of larval rockfishes Sebastes spp. across nearshore fronts in a coastal upwelling region. Mar Ecol Prog Ser 242:215-228

Brodeur RD, Pearcy WG, Ralston S (2003) Abundance and distribution patterns of nekton and micronekton in the Northern California Current Transition Zone. J Oceanogr 59:515-535

Burkett E (1995) Marbled murrelet food habits and prey ecology. US For Serv Gen Tech Rep PSW GTR 152:223-246

Carter HR (1984) At-sea biology of the marbled murrelet (Brachyramphus marmoratus). MSc thesis, University of Manitoba, Winnipeg
Carter HR, Stein JL (1995) Molts and plumages in the annual cycle of the marbled murrelet. US For Serv Gen Tech Rep PSW GTR 152:99-112

Castro CG, Chavez FP, Collins CA (2001) The role of the California Undercurrent in the export of denitrified waters from the eastern tropical North Pacific. Global Biogeochem Cycles 15:819-830

Chavez FP, Pennington TJ, Ryan JP, Michisaki RP and 5 others (2002) Biological and chemical consequences of the 1997-1998 El Nino in central California waters. Prog Oceanogr 54:205-232

Chavez FP, Ryan J, Lluch-Cota SE, Niquen C (2003) From anchovies to sardines and back: multidecadal change in the Pacific Ocean. Science 299:217-221

Clarke A, Prince PA (1980) Chemical composition and calorific value of food fed to mollymauk chicks (Diomedea melanophris) and D. chrysostoma at Bird Island, South Georgia. Ibis 122:488-494

Hare SR, Mantua NJ (2000) Empirical evidence for Northeast Pacific regime shifts in 1977 and 1989. Prog Oceanogr 47: 103-145

Henkel LA, Harvey JT (2006) Potential prey resources for marbled murrelets in central California. Calif Fish Game 92:191-206

Hobson KA (1990) Stable isotope analysis of marbled murrelets: evidence for freshwater feeding and determination of trophic level. Condor 92:897-903

Hobson KA, Piatt JF, Pitocchelli J (1994) Using stable isotopes to determine seabird trophic relationships. J Anim Ecol 63: 786-798

Jackson JBC, Kirby MX, Berger WH, Bjorndal KA and 15 others (2001) Historical overfishing and the collapse of coastal ecosystems. Science 293:629-638

Lavaniegos BE, Ohman MD (2003) Long term changes in pelagic tunicates of the California Current. Deep-Sea Res II 50:2493-2518

Leet WS, Dewees CM, Klingbeil R, Larson EJ (2001) California's living marine resources: a status report. University of California, Agriculture and Natural Resources, Berkeley and Los Angeles, CA

Litzow MA, Piatt JF, Prichard AK, Roby DD (2002) Response of pigeon guillemots to variable abundance of high-lipid and low-lipid prey. Oecologia 132:286-295

Marinovic BB, Croll DA, Gong N, Benson SR, Chavez FP (2002) Effects of the 1997-1999 El Niño and La Niña events on zooplankton abundance and euphausiid community composition within the Monterey Bay coastal upwelling system. Prog Oceanogr 54:265-277

Martensson P, Nordoy E, Blix A (1994) Digestibility of krill (Euphausia superba and Thysanoessa sp.) in minke whales (Balaenoptera acutorostrata) and crab-eater seals (Lobodon carcinophagus). Br J Nutr 72:713-716

McGowan JA, Cayan DR, Dorman LM (1998) Climate-ocean variability and ecosystem response in the Northeast Pacific. Science 281:210-217

Miller AK, Sydeman WJ (2004) Rockfish response to lowfrequency ocean climate change as revealed by the diet of a marine bird over multiple time scales. Mar Ecol Prog Ser 281:207-216

Nelson SK, Peck RW (1995) Behavior of marbled murrelets at nine nest sites in Oregon. Northwest Nat 76:43-53

Overland JE, Bond N, Yang M (2004) Ocean and climate changes. In: North Pacific ecosystem status. PICES Press, Sidney

Parrish JK, Zador SG (2003) Seabirds as indicators: an exploratory analysis of physical forcing in the Pacific Northwest coastal environment. Estuaries 26:1044-1057 
Pauly D, Christensen V, Dalsgaard J, Froese R, Torres F Jr (1998) Fishing down marine food webs. Science 279: 860-863

Peery MZ, Beissinger SR, Newman SH, Becker BH, Burkett EB, Williams TD (2004a) Individual and temporal variation in inland flight behavior of marbled murrelets: implications for population monitoring. Condor 106: 344-353

Peery MZ, Beissinger SR, Newman SH, Burkett EB, Williams TD (2004b) Applying the declining population paradigm: diagnosing causes of poor reproduction in the marbled murrelet. Conserv Biol 18:1088-1098

Peery MZ, Becker BH, Beissinger SR (2006) Combining demographic and count-based approaches to identify source-sink dynamics: an example using an endangered seabird. Ecol Appl 16:1516-1528

Peery MZ, Becker BH, Beissinger SR (in press) Age ratios as estimators of productivity: testing assumptions on an endangered seabird, the marbled murrelet. Auk

Phillips DL, Gregg JW (2001) Uncertainty in source partitioning using stable isotopes. Oecologia 127:171-179

Phillips DL, Newsome SD, Gregg JW (2005) Combining sources in stable isotope mixing models: alternative methods. Oecologia 144:520-527

Piatt JF (1990) The aggregative response of common murres and Atlantic puffins to schools of capelin. Stud Avian Biol 14:36-51

Rau GH, Ohman MD, Pierrot-Bults A (2003) Linking climate variability to nitrogen dynamics off Central California: a 50 year record based on $15 \mathrm{~N} / 14 \mathrm{~N}$ in CalCOFI zooplankton. Deep-Sea Res 50:2431-2447

Rodionov SN (2004) A sequential algorithm for testing climate regime shifts. Geophys Res Lett 31:Art. No. L09204

Sæther BE (2000) Weather ruins winter vacations. Science 288:1975-1976

Schwing FB, Murphree T, Green PM (2002) The Northern Oscillation Index (NOI): a new climate index for the northeast Pacific. Prog Oceanogr 53:115-139

Sealy SG (1975) Feeding ecology of ancient and marbled murrelets near Langara Island, BC. Can J Zool 53:418-433

Editorial responsibility: Rory Wilson (Contributing Editor), Swansea, UK
Sidwell VD (1981) Chemical and nutritional composition of finfishes, whales, crustaceans, mollusk, and their products, NOAA Tech Memo NMFS F/SEC-11

Sillett TS, Holmes RT, Sherry TW (2000) Impacts of a global climate cycle on the population dynamics of a migratory songbird. Science 288:2040-2042

Smith S, Adams P (1988) Daytime surface swarms of Thysanoessa spinifera (Euphausiacea) in the Gulf of the Farallones, California. Bull Mar Sci 42:76-84

Spear LB (1993) Dynamics and effect of western gulls feeding in a colony of guillemots and Brant's cormorants. J Anim Ecol 62:399-414

SPSS (1998) Systat 8.0 for Windows. Systat Corporation, Evanston, IL

Starr RM, Cope JM, Kerr LA (2002) Trends in fisheries and fisheries resources associated with the Monterey Bay National Marine Sanctuary from 1981-2000. California Sea Grant College Program, NOAA, La Jolla, CA

Sydeman WJ, Hobson KA, Pyle P, McLaren EB (1997) Trophic relationships among seabirds in central California: combined stable isotope and conventional dietary approach. Condor 99:327-336

Sydeman WJ, Hester MM, Thayer JA, Gress F, Martin P, Buffa J (2001) Climate change, reproductive performance and diet composition of marine birds in the southern California Current system, 1969-1997. Prog Oceanogr 49:309-329

Thomas DW, Blondel J, Perret P, Lambrechts MM, Speakman JR (2001) Energetic and fitness costs of mismatching resource supply and demand in seasonally breeding birds. Science 291:2598-2600

Thompson DR, Furness RW (1995) Stable-isotope ratios of carbon and nitrogen in feathers indicate seasonal dietary shifts in Northern Fulmars. Auk 112:493-498

Vanderklift MA, Ponsard S (2003) Sources of variation in consumer-diet $15 \mathrm{~N}$ enrichment: a meta-analysis. Oecologia 136:169-182

Winder M, Schindler DE (2004) Climate change uncouples trophic interactions in an aquatic ecosystem. Ecology 85: 2100-2106

Submitted: October 13, 2005; Accepted: April 10, 2006

Proofs received from author(s): November 24, 2006 